\title{
Obravnava vročinskih valov in primer toplotne obremenitve delavcev v kmetijstvu v času vročinskih valov 2017
}

\author{
Tjaša POGAČAR ${ }^{* 1}$, Lučka KAJFEŽ BOGATAJ ${ }^{2}$, Zalika ČREPINŠEK ${ }^{3}$
}

Received July 09, 2018; accepted October 03, 2018.

Delo je prispelo 09. julija 2018, sprejeto 03. oktobra 2018.

\begin{abstract}
IZVLEČEK
Delavci v kmetijstvu so poleti v veliki meri izpostavljeni vročinskemu stresu, kar lahko vpliva na zmanjšano storilnost in izgubo dohodka. Temperature zraka v Sloveniji v zadnjih desetletjih naraščajo, projekcije podnebnih sprememb pa kažejo, da se bo ta trend nadaljeval hkrati s povečanjem števila dni $\mathrm{z}$ vročinskim stresom. Analizirali smo spremembe $\mathrm{v}$ številu vročinskih valov v osrednji in jugozahodni Sloveniji za obdobje 1961-2017 ter obremenitev delavcev z vročinskim stresom med vročinskimi valovi na primeru leta 2017. Vročinski val nastopi, če je temperaturni prag za povprečno dnevno temperaturo dosežen ali presežen vsaj tri zaporedne dni, pri čemer je prag za omiljeno celinsko podnebje (Ljubljana) $24{ }^{\circ} \mathrm{C}$ in za omiljeno sredozemsko podnebje (Bilje) $25^{\circ} \mathrm{C}$. Kazalnik za spremljanje toplotne obremenitve delavcev WBGT (Wet Bulb Globe Temperature) smo izračunali iz temperatur zraka in zračne vlage. $\mathrm{Na}$ obeh lokacijah se povečuje število dni $\mathrm{v}$ vročinskih valovih in njihova intenzivnost, povprečne dnevne temperature zraka dosegajo precej večje vrednosti kot $\mathrm{V}$ prvi polovici obravnavanega obdobja. Podaljšuje se tudi časovni razpon, v katerem se pojavljajo, saj se do leta 1990 vročinski valovi niso pojavljali zgodaj junija in pozno avgusta, tako kot v zadnjih letih. Izračunane vrednosti kazalnika WBGT kažejo, da je bila v večini dni v vročinskih valovih 2017 v Ljubljani in Biljah mejna vrednost WBGT $23{ }^{\circ} \mathrm{C}$ presežena praktično cel dan, kar za delavce $\mathrm{z}$ veliko fizično obremenitvijo pomeni visoko stopnjo tveganja zaradi obremenitve $\mathrm{z}$ vročinskim stresom. Pri preseženih mejnih vrednostih WBGT bi morali delodajalci oziroma kmetje sami uvesti preventivne ukrepe za zmanjšanje tveganja vročinskega stresa.
\end{abstract}

Ključne besede: vročinski val; vročinski stres; kazalnik WBGT; kmetijstvo; delavci; Slovenija

\author{
ABSTRACT
HEAT WAVES ANALYSIS AND THE HEAT LOAD OF AGRICULTURAL WORKERS DURING THE HEAT WAVES IN 2017 (USING INDEX WBGT)

Workers in agriculture are regularly exposed to heat stress during summer, which can affect reduced labour productivity and income losses. Air temperatures in Slovenia have been rising in recent decades, and climate change projections show that this trend will continue along with an increase in the number of days with heat stress risk. Changes in the number of heat waves in central and south-western Slovenia for the period 1961-2017 were analysed as well as the risk of the heat stress for workers during heat waves in the year 2017. The heat wave occurs if the temperature threshold for the average daily temperature is reached or exceeded on at least three consecutive days, with the threshold for the mild continental climate (Ljubljana) $24{ }^{\circ} \mathrm{C}$ and the mild Submediterranean climate (Bilje) $25{ }^{\circ} \mathrm{C}$. The WBGT (Wet Bulb Globe Temperature) index, assessing the risk of heat stress, was calculated from relative humidity and air temperatures. At both locations, the number of days in heat waves increased as well as their intensity, average daily air temperatures were significantly higher than in the first half of the considered period. The time span, in which the heat waves occur, also extended, as until 1990 they did not appear in early June and late August, as in recent years. The calculated values of the WBGT show that for most days in the heat waves in 2017 in Ljubljana and Bilje, the WBGT $23{ }^{\circ} \mathrm{C}$ threshold was exceeded practically all day, which shows a high level of heat stress risk for physically intense work. In the case of exceeded WBGT reference values, employers or farmers themselves should take actions to reduce the risk of heat stress.

Key words: heat wave; heat stress; WBGT index; agriculture; workers; Slovenia

\footnotetext{
1 dr., Univerza v Ljubljani, Biotehniška fakulteta, Oddelek za agronomijo, Jamnikarjeva ulica 101, 1000 Ljubljana,Slovenija; ${ }^{*}$ Corresponding author: tjasa.pogacar@bf.uni-lj.si

2 prof. dr., Univerza v Ljubljani, Biotehniška fakulteta, Oddelek za agronomijo, Jamnikarjeva ulica 101, 1000 Ljubljana, Slovenija

3 doc. dr., Univerza v Ljubljani, Biotehniška fakulteta, Oddelek za agronomijo, Jamnikarjeva ulica 101, 1000 Ljubljana, Slovenija
} 


\section{UVOD}

Delo na prostem pomeni izpostavljenost okoljskim razmeram, ki se $\mathrm{s}$ podnebnim spremembami $\mathrm{v}$ zadnjih letih močno spreminjajo. V Sloveniji naraščajo povprečne temperature zraka še intenzivneje kot drugod po Evropi in svetu, v obdobju 1961-2011 je bil izmerjen časovni trend povprečne letne temperature zraka okoli $0,34{ }^{\circ} \mathrm{C} /$ desetletje, prav tako je pozitiven trend najvišje julijske temperature zraka, ki ga navaja Agencija RS za okolje (ARSO, 2013). Zmerno optimistični scenarij (RCP4.5) v obdobju 2011-2040 predvideva dvig povprečne temperature zraka za 0,5 do $1,0{ }^{\circ} \mathrm{C}$, v obdobju $2041-2070$ za 1,0 do $2,0^{\circ} \mathrm{C}$, v obdobju $2071-$ 2100 pa za 1,3 do $2,6^{\circ} \mathrm{C}$ (ARSO, 2017). Za povprečno poletno in najvišjo julijsko temperaturo zraka kažejo projekcije za konec stoletja po najbolj optimističnem scenariju (RCP2.6) povečanje za $1{ }^{\circ} \mathrm{C}$ in po najmanj optimističnem (RCP8.5) za $4.5^{\circ} \mathrm{C}$, pri vročih dneh (najvišja dnevna temperatura zraka enaka ali višja od $30{ }^{\circ} \mathrm{C}$ ) to pomeni povečanje za od 2 do 35 dni (Pogačar in sod., 2018).

Po podatkih FAO (Staal Wästerlund, 2018) je $32 \%$ svetovne delovne populacije zaposlene $\mathrm{v}$ kmetijskem sektorju, v katerem je izmed vseh panog najvišja stopnja smrtnosti zaradi vročine, saj delo večinoma poteka na prostem. Razmere se zaradi globalnega segrevanja še slabšajo, zato so raziskave na tem področju nujne, kar je prepoznala tudi Evropa, ki tem vprašanjem namenja dodatna finančna sredstva (projekt Heat-Shield: https://www.heat-shield.eu/).

Delavci v kmetijstvu so pri svojem delu poleti v veliki meri izpostavljeni vročinskemu stresu, pri čemer je obremenitev zaradi fizične zahtevnosti opravil, pri kateri telo proizvaja dodatno toploto, velika tudi $\mathrm{v}$ zmernejših razmerah (Staal Wästerlund, 2018). Dodatno težavo lahko predstavlja zaščitna obleka, kadar je potrebna zaradi narave dela, saj ne omogoča zadostnega odvajanja toplote v okolico in omejuje potenje. Delavci v velikem deležu poročajo o žeji, povečanem potenju, utrujenosti, glavobolih, v manjšem deležu tudi o hujših simptomih vročinskega stresa, oboje pa brez ukrepanja vodi v zmanjšano storilnost (Pogačar in sod., 2017). Vročinski stres zmanjša celotno produktivnost in posledično pomeni izgubo dohodka (Kjellstrom in sod., 2009). Dehidriranost vodi v počasnejše delo, večja je verjetnost napak, kar lahko povzroči delovne nesreče (Kjellstrom in sod., 2018), povečana je tudi možnost za vročinski udar (t.j. kap) (Staal Wästerlund, 2018). V raziskavi v ZDA so ugotovili, da je tveganje za smrt zaradi vročinskega udara pri delavcih $\mathrm{v}$ kmetijstvu 35krat večja kot pri povprečni delovni populaciji (Gubernot in sod., 2015).

Pomembno je, da spremljamo vročinski stres na delovnem mestu, a vendar $\mathrm{v}$ tej smeri predvsem $\mathrm{v}$ zmernih podnebjih, kjer do sedaj ni bilo večjih težav, še ni veliko raziskav. Nikjer nismo zasledili analize toplotne obremenitve evropskih delavcev v kmetijstvu, najbližje so s svojimi raziskavami Flouris in sod. (2018), ki so raziskovali občutljivost ljudi na vročinski stres pri vsakdanjih opravilih in pri težjem delu, in Ioannou in sod. (2017), ki so ob razvijanju metode določanja produktivnosti $\mathrm{s}$ pomočjo snemanja časovnega poteka dela spremljali tudi toplotno obremenitev delavcev. $\mathrm{Na}$ splošno se $\mathrm{v}$ toplotno obremenjenih okoljih za spremljanje obremenitve delavcev oz. spremljanje vročinskega stresa $v$ največji meri uporablja kazalnik WBGT (Wet Bulb Globe Temperature), ki ga izračunamo iz temperature in vlažnosti zraka in ga kot kazalnik toplotne obremenitve na delovnem mestu priporoča ISO standard. V okviru EU projekta Heat-Shield je bil izbran WBGT, ker je najširše uporabljen kazalnik za določanje vročinskega stresa pri delavcih, saj ga lahko izračunamo iz standardnih meteoroloških meritev na klasičnih ali avtomatskih postajah in je enostaven za interpretacijo $\mathrm{z}$ uporabo mednarodnih standardov, kot sta ISO 1989 in ISO 2017. Nazorneje so ga $\mathrm{v}$ primerjavi $\mathrm{z}$ drugimi kazalniki predstavili Gao in sod. (2018), ki glede na d'Ambrosio Alfano in sod. (2016) opozarjajo, da kljub široki možnosti uporabe ni primeren pri veliki vlagi $\mathrm{v}$ zraku in zelo počasnemu gibanju zraka ter da ne upošteva tveganja za dehidracijo pri povečanem potenju. Za Slovenijo kažejo projekcije podnebnih sprememb podobno kot za poletne temperature povečanje povprečnih in največjih poletnih vrednosti WBGT za 1 do $3,5^{\circ} \mathrm{C}$ ter povečanje števila dni z veliko obremenjenostjo $\mathrm{z}$ vročinskim stresom (WBGT večji od $27^{\circ} \mathrm{C}$ ) do 20 dni v osrednji Sloveniji in več kot 30 dni v Biljah po najmanj optimističnem scenariju (Pogačar in sod., 2018).

Namen prispevka je predstaviti, kako se povečuje število vročinskih valov $\mathrm{v}$ osrednji Sloveniji in na jugozahodu ter kakšna je obremenitev delavcev $\mathrm{z}$ vročinskim stresom med vročinskimi valovi, kar bomo prikazali na primerih podatkov iz leta 2017. 


\section{MATERIAL IN METODE DELA}

\subsection{Obravnava vročinskih valov v daljšem obdobju}

Za dve lokaciji, Ljubljano (14³1', 46²', 299 m n.m.v.)

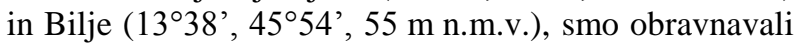
vročinske valove v obdobju 1961-2017 (v Biljah od 1970, ko so dostopni podatki). Vročinski val nastopi, če je temperaturni prag za povprečno dnevno temperaturo dosežen ali presežen vsaj tri zaporedne dni, pri čemer je prag za vlažno in zmerno podnebje hribovitega sveta $22{ }^{\circ} \mathrm{C}$, za omiljeno celinsko podnebje (Ljubljana) $24^{\circ} \mathrm{C}$ in za omiljeno sredozemsko podnebje (Bilje) $25^{\circ} \mathrm{C}$ (Ključevšek in sod., 2018). Grafično smo prikazali število dni v vročinskem valu po mesecih za vsako leto in povprečno dnevno temperaturo po dnevih za vsak vročinski val. Podatke o povprečnih dnevnih temperaturah zraka smo pridobili iz arhiva Agencije RS za okolje (ARSO).

\subsection{Obravnava polurnih vrednosti toplotne obremenitve s kazalnikom WBGT}

Polurne vrednosti kazalnika WBGT $\left[{ }^{\circ} \mathrm{C}\right]$ v senci smo na podlagi polurnih vrednosti temperature zraka $\left(T_{a}\left[{ }^{\circ} \mathrm{C}\right]\right)$ in psihrometrične temperature mokrega termometra $\left(T_{p w b}\left[{ }^{\circ} \mathrm{C}\right]\right)$, izračunali po enačbi (Lemke in Kjellstrom, 2012 po Bernard in Pourmoghani 1999):

$W B G T=0,67 T_{p w b}+0,33 T_{a}$,

pri čemer je $T_{p w b}$ je temperatura zraka pri umetno ustvarjenih razmerah, ko je hitrost vetra $3-5 \mathrm{~m} \mathrm{~s}^{-1}$ in jo $\mathrm{z}$ iteracijo določimo iz $T_{a}$, temperature rosišča $T_{d}\left[{ }^{\circ} \mathrm{C}\right]$, delnega parnega tlaka $e_{d}[\mathrm{hPa}]$ in nasičenega parnega tlaka $e_{w}[\mathrm{hPa}]$ (McPherson, 2008):

$$
\begin{aligned}
& 1556 e_{d}-1,484 e_{d} T_{p w b}-1556 e_{w}+1,484 e_{w} T_{p w b}+1010\left(T_{a}-T_{p w b}\right)=0, \\
& e_{d}=6,106 \exp \left(\frac{17,27 T_{d}}{237,3+T_{d}}\right), \\
& e_{w}=6,106 \exp \left(\frac{17,27 T_{p w b}}{237,3+T_{p w b}}\right),
\end{aligned}
$$

Za izračun $T_{d}$ in $e_{d}$ potrebujemo podatke o relativni zračni vlagi. Podatke o terminskih vrednostih $T_{a}$ in relativne vlage vsake pol ure $\mathrm{v}$ času vročinskih valov $\mathrm{v}$ letu 2017 smo pridobili iz meritev avtomatskih postaj, $\mathrm{ki}$ so shranjene $\mathrm{v}$ arhivu ARSO. Preglednica 1 predstavlja ISO standard mejnih vrednosti kazalnika
WBGT za aklimatizirane in ne-aklimatizirane delavce, ki so določene tako, da pri uporabi lahkotnih oblačil (kratka majica in hlače) telesna temperatura ne preseže $38^{\circ} \mathrm{C}$, kar bi pomenilo preveliko toplotno obremenitev oziroma vročinski stres (Staal Wästerlund, 2018).

Preglednica 1: Mejne vrednosti kazalnika WBGT po ISO standardu 7243 (1989) (Staal Wästerlund, 2018) glede na

\begin{tabular}{|c|c|c|c|c|}
\hline \multirow{2}{*}{$\begin{array}{l}\text { Stopnja metabolizma } \\
\mathrm{M}\left[\mathrm{W} / \mathrm{m}^{2}\right]\end{array}$} & \multicolumn{4}{|c|}{ Mejna vrednost kazalnika WBGT $\left[{ }^{\circ} \mathrm{C}\right]$} \\
\hline & \multicolumn{2}{|c|}{ Aklimatizirana oseba } & \multicolumn{2}{|c|}{ Ne-aklimatizirana oseba } \\
\hline$M \leq 65$ & \multicolumn{2}{|c|}{33} & \multicolumn{2}{|c|}{33} \\
\hline $65<M \leq 130$ & \multicolumn{2}{|c|}{30} & \multicolumn{2}{|c|}{30} \\
\hline $130<M \leq 200$ & \multicolumn{2}{|c|}{28} & \multicolumn{2}{|c|}{28} \\
\hline $200<M \leq 260$ & $\begin{array}{l}\text { Brez občutnega } \\
\text { gibanja zraka } \\
25\end{array}$ & $\begin{array}{l}\text { Občutno gibanje } \\
\text { zraka } \\
\\
26\end{array}$ & $\begin{array}{l}\text { Brez občutnega } \\
\text { gibanja zraka } \\
22\end{array}$ & $\begin{array}{l}\text { Občutno gibanje } \\
\text { zraka } \\
\quad 23\end{array}$ \\
\hline$M>260$ & 23 & 25 & 18 & 20 \\
\hline
\end{tabular}
stopnjo metabolizma

Table 1: Wet-bulb globe temperature index reference values, according to ISO 7243 (1989) (Staal Wästerlund, 2018) 


\section{REZULTATI}

\subsection{Vročinski valovi v Ljubljani in Biljah}

Število dni v vročinskih valovih je začelo po letu 1990 močno naraščati. V Ljubljani, ki ima omiljeno celinsko podnebje, so nastopili po letu 1988 vročinski valovi prav vsako leto, z izjemo leta 1997, okoli 20 do 30 dni v vročinskih valovih vsako poletje je postalo stalnica (Slika 1). V tem času so postali običajni tudi vročinski valovi v juniju (zgornji, svetel del stolpcev). Najbolj ekstremno po številu dni je bilo leto 2003, ko so se vročinski valovi vrstili en za drugim tekom celotnega poletja (Slika 2). Temnejše barve nakazujejo, da se ne povečuje le število dni $\mathrm{v}$ vročinskih valovih, temveč tudi njihova intenzivnost, saj povprečne dnevne temperature zraka dosegajo precej večje vrednosti kot $\mathrm{v}$ prvi polovici obravnavanega obdobja.

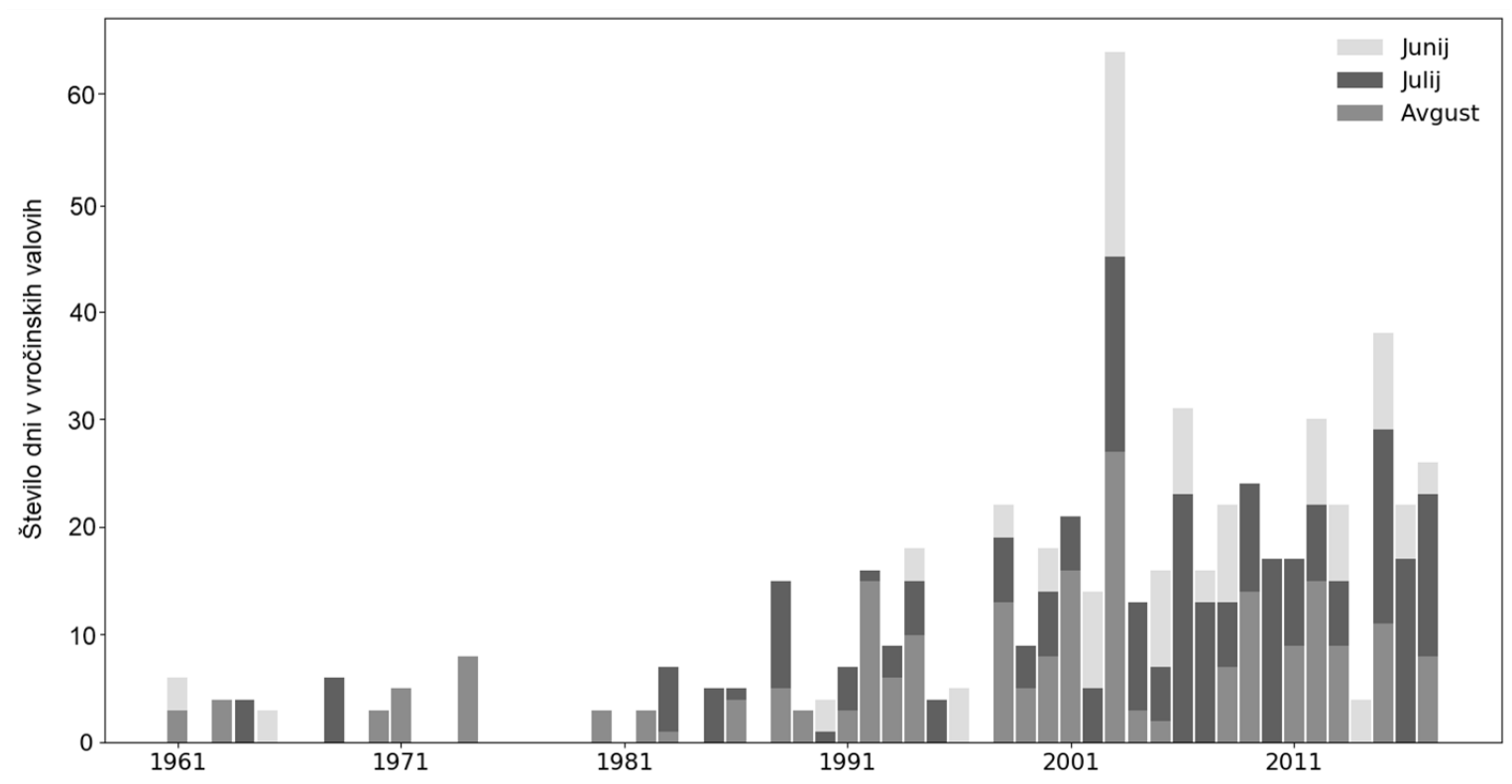

Slika 1: Število dni v vročinskih valovih po mesecih in letih v obdobju 1961-2017 v Ljubljani

Figure 1: Number of days within heat waves in months and years in the period 1961-2017 in Ljubljana 


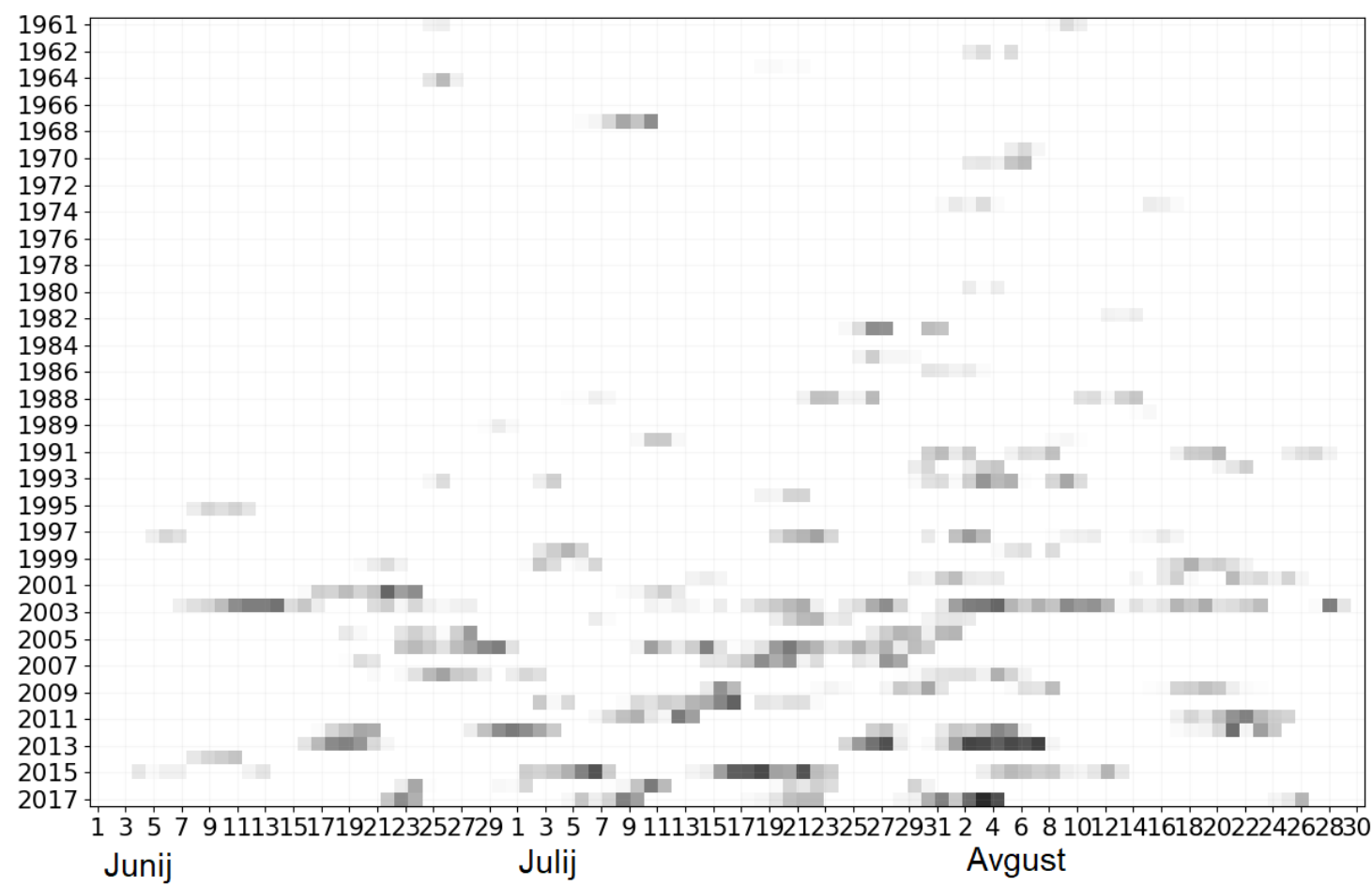

Slika 2: Ljubljana od 1. junija do 31. avgusta v obdobju 1961-2017: dnevi v vročinskem valu so obarvani sivo (višja povprečna dnevna temperatura zraka je predstavljena s temnejšo barvo) (različica do leta 2015 objavljena v Kajfež Bogataj in sod., 2018)

Figure 2: Ljubljana from June 1 to August 31 in the period 1961-2017: days in heat waves are colored grey (higher average daily air temperature is represented with darker color) (version until 2015 was published in Kajfež Bogataj et al., 2018)

Stanje je podobno $\mathrm{v}$ Biljah, ki imajo omiljeno sredozemsko podnebje, kjer je prag za nastop vročinskega vala $1{ }^{\circ} \mathrm{C}$ višji kot $\mathrm{v}$ omiljenem celinskem podnebju. Poleg leta 1997 so bila tu brez vročinskih valov še leta 1991, 1998, 2000 in 2001 (Slika 3). Tudi tu je bilo najbolj ekstremno leto 2003, vendar z manjšim številom dni v vročinskih valovih kot Ljubljana. Sledijo leta 2012, 2015 in 2013. Podobno kot v Ljubljani, so tudi $\mathrm{v}$ Biljah povprečne dnevne temperature zraka $\mathrm{v}$ vročinskih valovih $\mathrm{v}$ zadnjih letih višje. Na obeh lokacijah je jasno vidno, da se pred letom 1990 vročinski valovi niso pojavljali zgodaj junija in pozno avgusta, $v$ zadnjih dveh desetletjih pa ni to nič nenavadnega. Razpon povprečnih dnevnih temperatur zraka v času vročinskih valov je bil v Ljubljani od 24 do $30{ }^{\circ} \mathrm{C}$ (doseženo v letih 2013 in 2017) in v Biljah od 25 do $30{ }^{\circ} \mathrm{C}$ (doseženo v letih 2012 in 2017). 


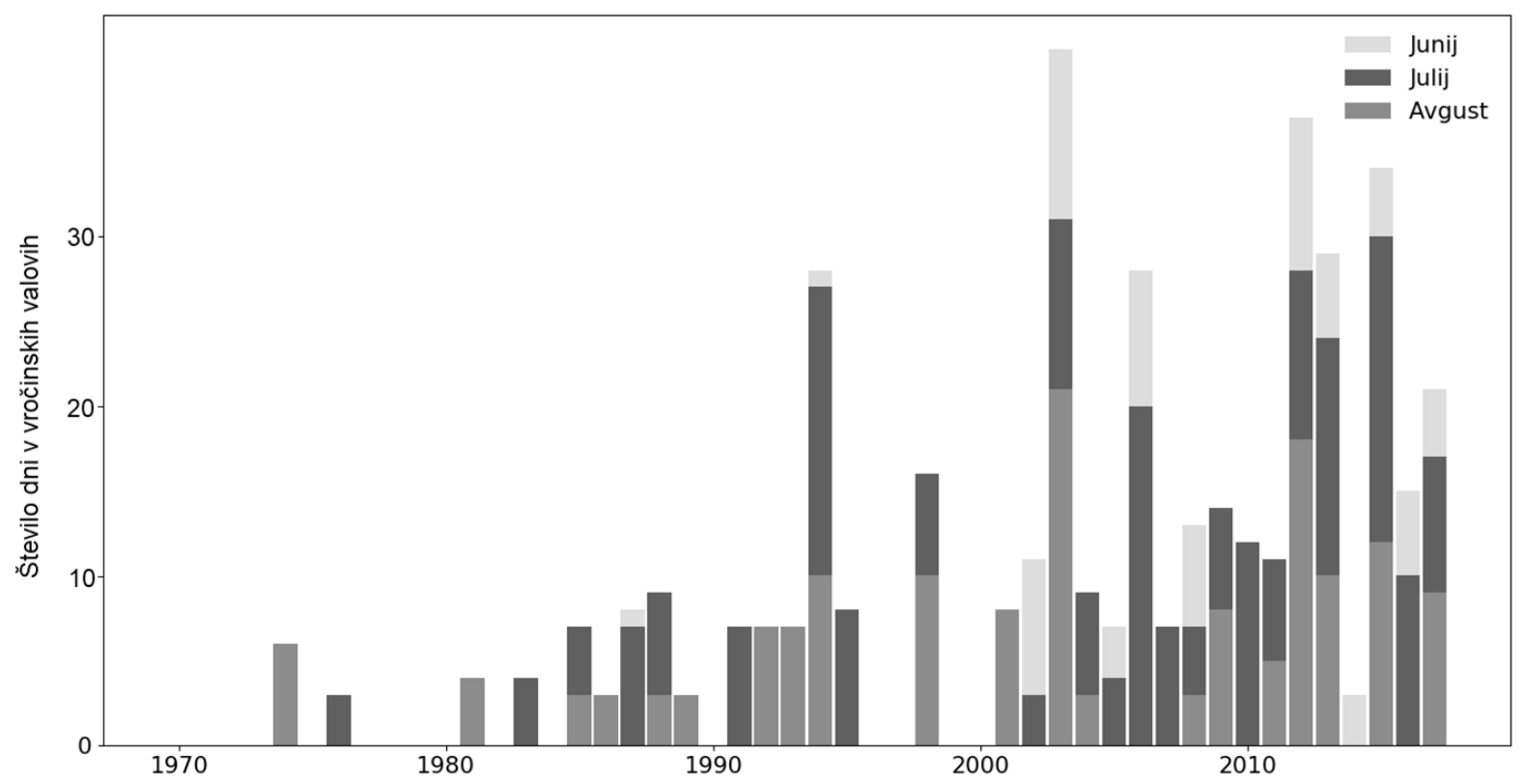

Slika 3: Število dni v vročinskih valovih po mesecih in letih v obdobju 1970-2017 v Biljah Figure 3: Number of days within heat waves in months and years in the period 1970-2017 in Bilje

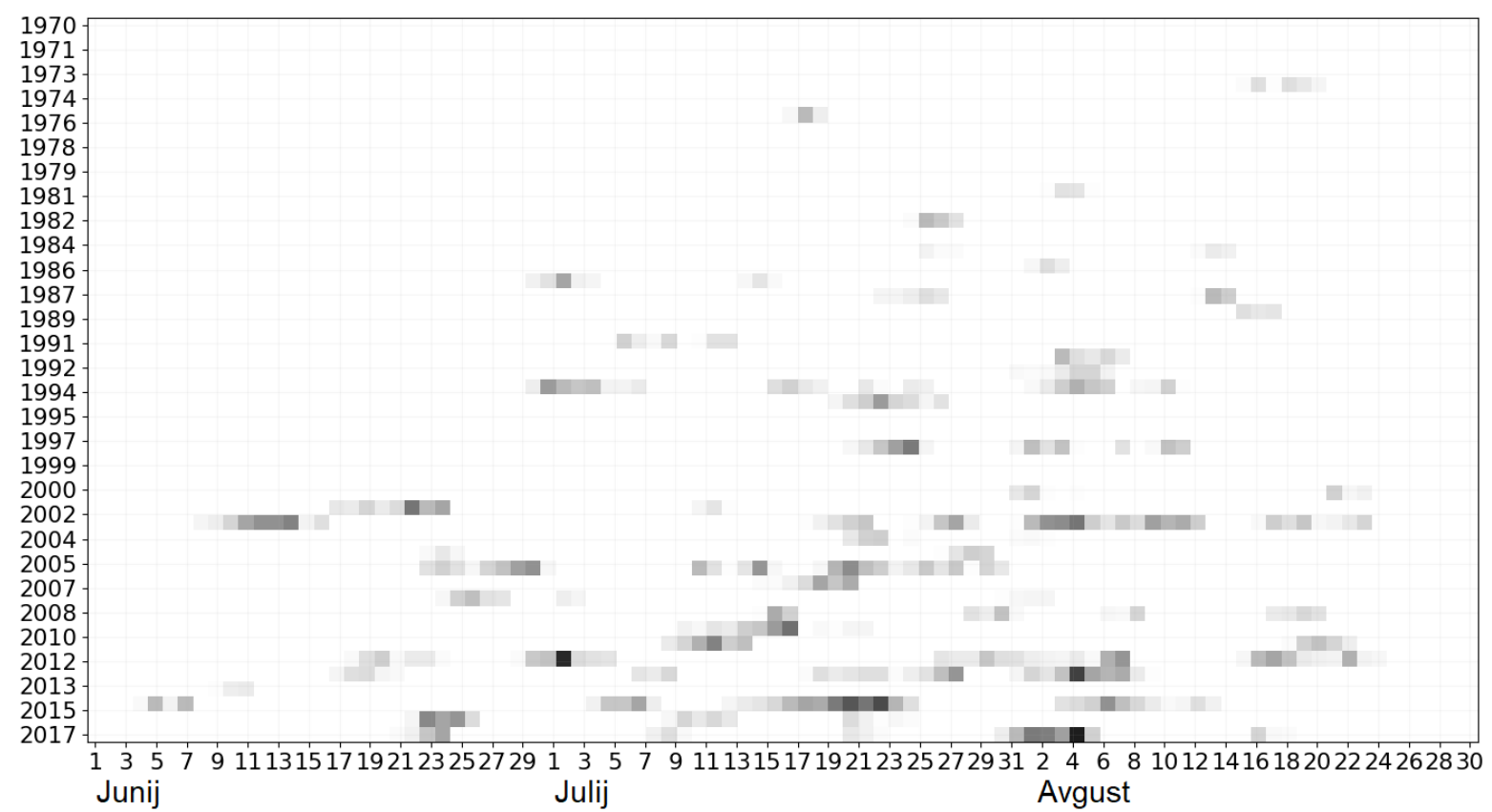

Slika 4.: Bilje od 1. junija do 31. avgusta v obdobju 1971-2017: dnevi v vročinskem valu obarvani sivo (višja povprečna dnevna temperatura zraka je predstavljena s temnejšo barvo)

Figure 4: Bilje from June 1 to August 31 in the period 1970-2017: days in heat waves are colored grey (higher average daily air temperature is represented with darker color)

\subsection{Polurne vrednosti toplotne obremenitve med vročinskim valovi v letu 2017}

Leta 2017 je tako v Ljubljani kot v Biljah nastopilo 5 vročinskih valov, dolgih od 3 do 7 (Bilje) oz. 8 (Ljubljana) dni. Za vsak vročinski val smo predstavili izmerjene polurne terminske vrednosti temperature zraka in izračunane vrednosti kazalnika WBGT. Te predstavljajo toplotno obremenitev delavcev, ob preseženih mejnih vrednostih gre za vročinski stres, ki negativno vpliva na počutje, zdravje in produktivnost. Pri različni stopnji fizične obremenjenosti morajo delavci upoštevati različne mejne vrednosti (Preglednica 1). V urah, ko so mejne vrednosti presežene, bi se 
delavci morali poskušati izogniti delu ali uporabiti omilitvene ukrepe. V Ljubljani (Slika 5) vrednosti kazalnika WBGT niso nikoli presegle mejne vrednosti $28^{\circ} \mathrm{C}$, v najhujšem vročinskem valu (Slika 5 spodaj) so od tretjega dne dalje vsak dan presegle vrednost $25^{\circ} \mathrm{C}$ za 6 do 9 ur (4 dni), v šestih dneh za 3 do 4 ure in $v$ dveh dneh za dve uri, z začetkom nekje med 11. in 14. uro. Meja WBGT $23{ }^{\circ} \mathrm{C}$ je bila v vseh vročinskih valovih presežena vsaj za nekaj ur, večinoma od 7 do 9 ur, v najhujšem vročinskem valu pa 10 do 15 ur, z začetkom običajno med 9 . in 11 . uro. V celotnem poletju niso vrednosti WBGT nikoli izven vročinskih valov presegle vrednosti $25^{\circ} \mathrm{C}$.
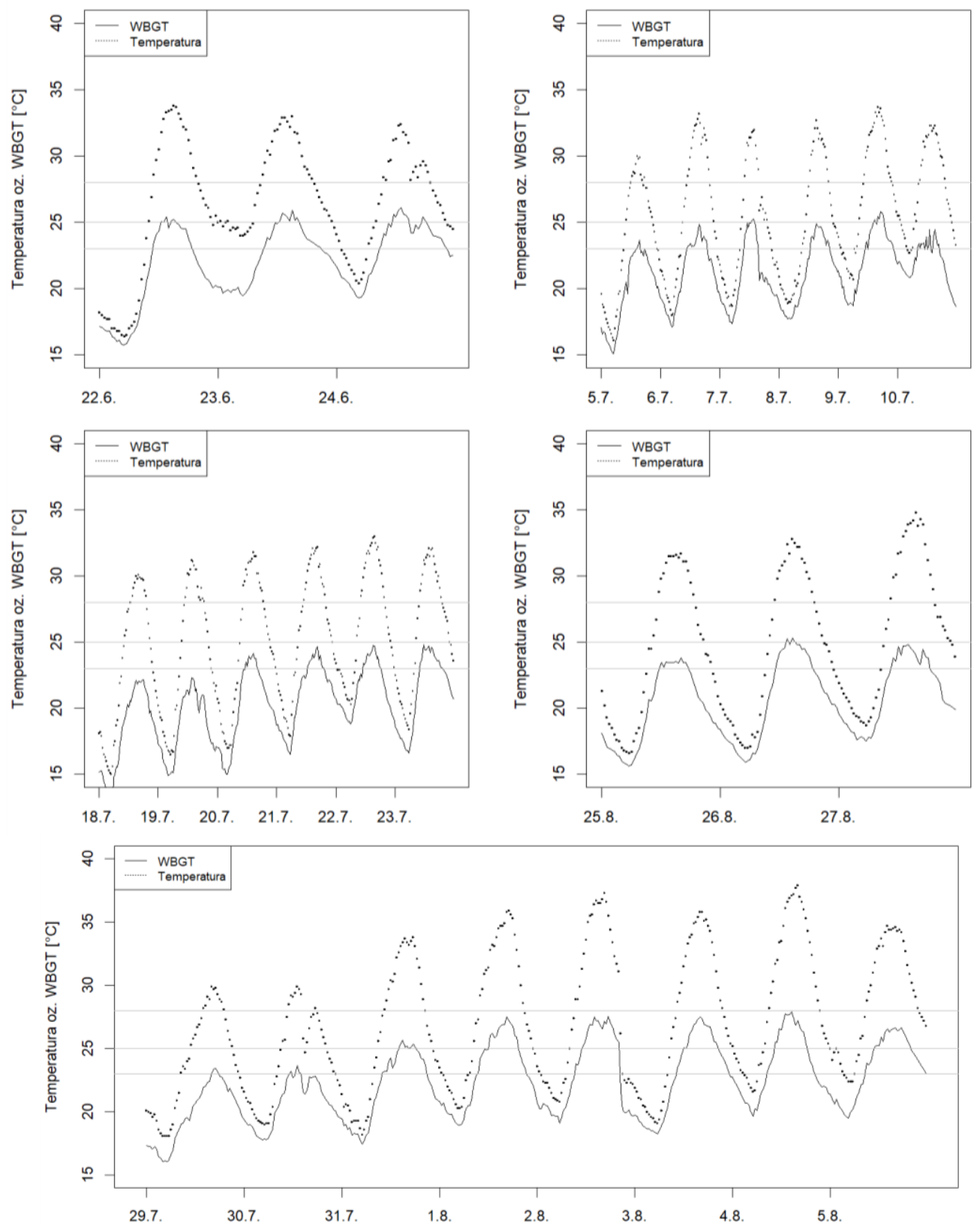

Slika 5: Polurne vrednosti temperature zraka in WBGT med vročinskimi valovi leta $2017 \mathrm{v}$ Ljubljani, z vodoravnimi linijami so označene nekatere mejne vrednosti za kazalnik WBGT iz Preglednice $1\left(23{ }^{\circ} \mathrm{C}, 25^{\circ} \mathrm{C}\right.$ in $28{ }^{\circ} \mathrm{C}$, ki za aklimatizirano osebo predstavljajo prag za stopnjo metabolizma več kot $260 \mathrm{~W} \mathrm{~m}^{-2}, 200$ do $260 \mathrm{~W} \mathrm{~m}^{-2}$ in 130 do $200 \mathrm{~W} \mathrm{~m}^{-2}$ )

Figure 5: Air temperatures and WBGT values every half hour during heat waves in the year 2017 in Ljubljana, reference WBGT values (see Table 1) are marked with horizontal lines $\left(23{ }^{\circ} \mathrm{C}, 25{ }^{\circ} \mathrm{C}\right.$ and $28{ }^{\circ} \mathrm{C}$, for acclimatized person representing threshold for metabolic rates more than $260 \mathrm{~W} \mathrm{~m}^{-2}, 200$ to $260 \mathrm{~W} \mathrm{~m}^{-2}$ and 130 to $200 \mathrm{~W} \mathrm{~m}^{-2}$, respectively 

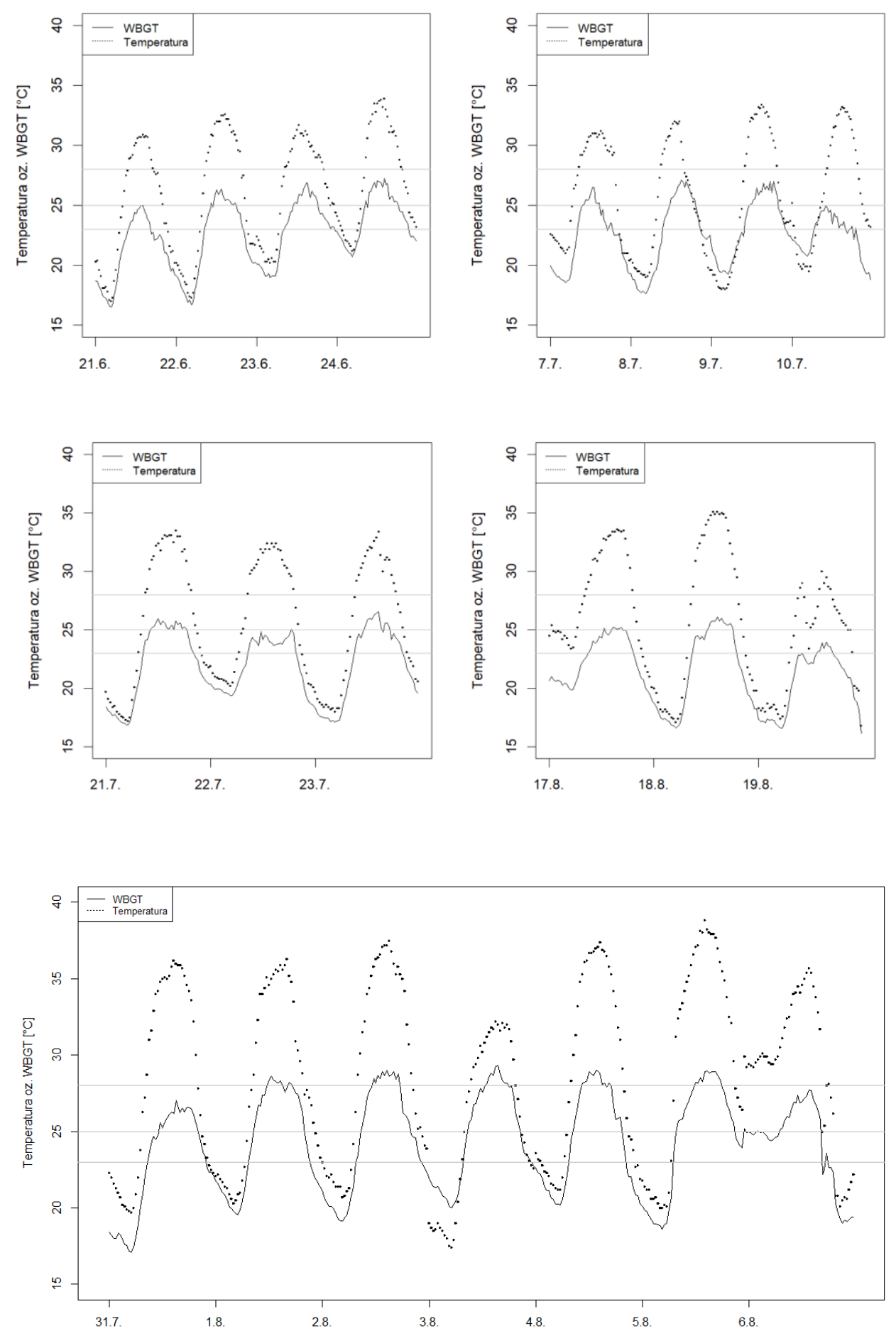

Slika 6: Polurne vrednosti temperature zraka in WBGT med vročinskimi valovi leta $2017 \mathrm{v}$ Biljah, z vodoravnimi linijami so označene nekatere mejne vrednosti za kazalnik WBGT iz Preglednice $1\left(23{ }^{\circ} \mathrm{C}, 25^{\circ} \mathrm{C}\right.$ in $28^{\circ} \mathrm{C}$, ki za aklimatizirano osebo predstavljajo prag za stopnjo metabolizma več kot $260 \mathrm{~W} \mathrm{~m}^{-2}, 200$ do $260 \mathrm{~W} \mathrm{~m}^{-2}$ in 130 do $200 \mathrm{~W} \mathrm{~m}^{-2}$ )

Figure 6: Air temperatures and WBGT values every half hour during heat waves in the year 2017 in Bilje, reference WBGT values (see Table 1) are marked with horizontal lines $\left(23{ }^{\circ} \mathrm{C}, 25{ }^{\circ} \mathrm{C}\right.$ and $28{ }^{\circ} \mathrm{C}$, for acclimatized person representing threshold for metabolic rates more than $260 \mathrm{~W} \mathrm{~m}^{-2}, 200$ to $260 \mathrm{~W} \mathrm{~m}^{-2}$ and 130 to $200 \mathrm{~W} \mathrm{~m}^{-2}$, respectively) 
Temperature zraka so $\mathrm{v}$ času vročinskih valov dnevno močno nihale, tudi za več kot $15{ }^{\circ} \mathrm{C}$, najvišje so segale $\mathrm{v}$ Ljubljani od 30 do $38^{\circ} \mathrm{C}$, najnižje pa od 15 do skoraj $24^{\circ} \mathrm{C}$. V Biljah (Slika 6) najnižje temperature zraka na splošno niso bile bistveno višje, morda le kakšno stopinjo, gibale so se v podobnem intervalu, najvišja dosežena temperatura zraka pa je bila $39^{\circ} \mathrm{C}$. Temperatura zraka in vlaga sta bili v Biljah glede na Ljubljano toliko bolj obremenilni, da je bila v vseh dneh $\mathrm{v}$ vročinskih valovih razen dveh presežena tudi mejna vrednost WBGT $25^{\circ} \mathrm{C}$. Mejna vrednost $23{ }^{\circ} \mathrm{C}$ je bila v času vročinskih valov $\mathrm{v}$ Biljah presežena večinoma nekje od 8. oziroma 9. ure dalje od 10 do 11 ur dnevno (tudi do 14, izjemoma po en dan 4 in 6 ur), enkrat pa se je celo zgodilo, da se ni prekinila od 7. ure zjutraj do 16 . ure naslednjega dne. Meja $25^{\circ} \mathrm{C}$ je bila večinoma presežena nekje od 9. do 12. ure dalje, največkrat za več kot 8 ur. Poleg tega pa je bila $\mathrm{v}$ Biljah $\mathrm{v}$ najhujšem vročinskem valu $\mathrm{v}$ začetku avgusta $\mathrm{v}$ petih dneh za vsaj pet ur med 12. in 17. uro (izjemoma med 10:30 in 17:30) presežena tudi mejna vrednost $28^{\circ} \mathrm{C}$.

Za lažjo predstavo je na primeru četrtega (najdaljšega) vročinskega vala $\mathrm{v}$ Biljah predstavljena odvisnost kazalnika WBGT od temperature zraka in relativne vlage (Slika 7). Največje vrednosti je kazalnik dosegal ob visokih temperaturah zraka in majhni vlagi, za manjše vrednosti WBGT pa se snop zlagoma širi proti večjim vrednostim vlage in manjšim vrednostim temperature zraka. $V$ času vročinskih valov je bil v vseh primerih precej tipičen potek, da se je relativna vlaga $\mathrm{Z}$ dviganjem temperature zraka tekom dneva zmanjševala in obratno.
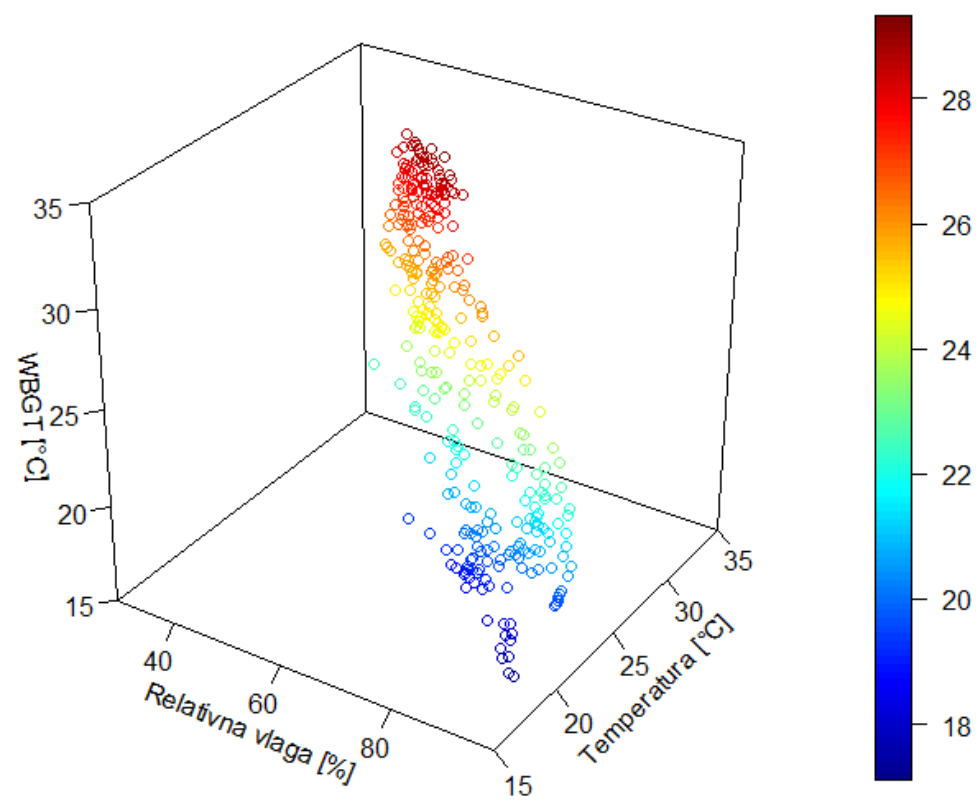

Slika 7: Polurne vrednosti WBGT v odvisnosti od temperature zraka in relativne vlage med 4. vročinskim valom leta 2017 v Biljah

Figure 7: WBGT values vs. air temperature and relative humidity every half hour during 4th heat wave in the year 2017 in Bilje

\section{DISKUSIJA}

$\mathrm{Z}$ naraščanjem temperature zraka se opazno povečuje število dni v vročinskih valovih in njihova intenzivnost, podaljšuje pa se tudi časovni razpon, $\mathrm{v}$ katerem se pojavljajo, kar potrjuje mnogo različnih raziskav kljub različnim definicijam vročinskih valov (npr. Morabito et al., 2017; Russo et al., 2015; Bittner et al., 2013; Kuglitsch in sod., 2010). Povprečna dnevna temperatura zraka je v Sloveniji uporabljena kot prag za določanje nastopa vročinskega vala, saj njena vrednost odraža informacijo o najnižji in najvišji temperaturi zraka ter relativni vlagi. Je dobra mera za jakost toplotne obremenitve, saj bo približno enaka za dolgotrajno obremenitev pri nekoliko nižjih temperaturah (majhna amplituda dnevnega temperaturnega hoda $\mathrm{v}$ vlažni zračni masi) ali kratkotrajno obremenitev pri višjih temperaturah $\mathrm{z}$ vmesno osvežitvijo (velika amplituda dnevnega temperaturnega hoda $\mathrm{v}$ suhi zračni masi) (Ključevšek in sod., 2018). Tako nam pove več kot le 
najvišje dnevne temperature zraka, kljub vsemu pa ljudje po naravi nimamo občutka za povprečje in $\mathrm{V}$ običajnem poletnem dnevu težko ocenimo, kakšna je bila povprečna dnevna temperatura zraka. Svojo ogroženost dojemamo na podlagi najvišjih dnevnih temperatur zraka in občutka, da nam je vroče. Pri rezultatih lahko približno ocenimo, da WBGT preseže $23{ }^{\circ} \mathrm{C}$ pri temperaturah zraka okoli $30^{\circ} \mathrm{C}$, medtem ko preseže $25^{\circ} \mathrm{C}$ običajno pri temperaturah zraka okoli $32{ }^{\circ} \mathrm{C}$, če ostaja vlaga v normalnih okvirih.

Za kmetijska opravila se glede na težavnost dela stopnja metabolizma giblje od 150 do $500 \mathrm{~W} \mathrm{~m}^{-2}$ (Preglednica 2). Lundgren in sod. (2014) so iz srčnega utripa in opazovanja štirih delavcev v Indiji za pripravo zemlje za obdelavo, sejanje, zalivanje, pletje, kontrolo škodljivcev, gnojenje, vzdrževanje rastlin, žetev ter vmesno hojo in sklanjanje ocenili stopnjo metabolizma na $190 \mathrm{~W} \mathrm{~m}^{-2}$. Pri lažjih delih, kot je oranje s traktorjem ali zgoraj našteto delo, lahko za mejo nevarne ogroženosti z vročinskim stresom upoštevamo mejo pri vrednosti WBGT $28^{\circ} \mathrm{C}$ (Preglednica 1), ki v Ljubljani v letu 2017 ni bila presežena, v Biljah pa le v najhujšem vročinskem valu po vsaj 5 ur dnevno, vedno vsaj med 12. in 17. uro. Pri nekoliko bolj zahtevnih delih, kot je na primer skobljanje lesa ali podiranje drevesa $\mathrm{z}$ motorno žago, je meja za kazalnik WBGT nižja - v mirnem ozračju $25^{\circ} \mathrm{C} \quad\left(\mathrm{z}\right.$ vetrom $\left.26^{\circ} \mathrm{C}\right)$ za aklimatizirane delavce in še nižja $22^{\circ} \mathrm{C}\left(\right.$ oz. $\left.23^{\circ} \mathrm{C}\right)$ za ne-aklimatizirane delavce. $\mathrm{V}$ večini dni $\mathrm{v}$ vročinskih valovih je bila leta 2017 tako v Ljubljani kot v Biljah meja $23{ }^{\circ} \mathrm{C}$ presežena praktično cel dan, kar za delavce pomeni visoko stopnjo tveganja zaradi obremenitve $\mathrm{z}$ vročinskim stresom. Pri zelo napornem fizičnem delu, kot je kopanje $\mathrm{z}$ lopato ali sekanje, je stanje $\mathrm{v}$ mirnem ozračju, ko kazalnik WBGT preseže $23^{\circ} \mathrm{C}$, nevarno že za aklimatizirane delavce (z vetrom pri $25^{\circ} \mathrm{C}$ ), za neaklimatizirane pa se lahko težave pojavijo že pri preseženih vrednostih $18 \mathrm{oz}$. $20^{\circ} \mathrm{C}$. Pri preseženih mejnih vrednostih WBGT bi morali delodajalci oz. kmetje sami uvesti preventivne ukrepe, kot so reorganizacija dela, več odmorov na hladnem, več zaužite tekočine ipd., da zmanjšajo tveganje vročinskega stresa (Staal Wästerlund, 2018).

Preglednica 2: Ocene stopnje metabolizma za nekaj kmetijskih opravil po ISO standardu (2004) (Staal Wästerlund, 2018)

Table 2: Estimates of metabolic rate for agricultural activities, according to ISO (2004) (Staal Wästerlund, 2018)

\begin{tabular}{l|c}
\hline Opravilo & Stopnja metabolizma ${\mathrm{M}\left[\mathrm{W} \mathrm{m}^{-2}\right]}^{-2}$ \\
\hline Sekanje (2 kg težka sekira, 33 udarcev na minuto) & 380 \\
\hline Kopanje z lopato (24 dvigov na minuto) & 235 \\
\hline Podiranje drevesa z motorno žago & 225 \\
\hline Skobljanje lesa & 205 \\
\hline Obrezovanje sadnega drevja & 185 \\
\hline Prenašanje tovora (10 kg pri hitrosti hoje $10 \mathrm{~km} / \mathrm{h})$ & 170 \\
\hline Grabljenje listja & 170 \\
\hline Oranje s traktorjem & \\
\hline
\end{tabular}

Za primerjavo, delavci na poljih sladkornega trsa $\mathrm{v}$ Kostariki v precej bolj vročem podnebju so v letih 2010 in 2011 delali pri vrednostih WBGT med $20^{\circ} \mathrm{C}$ in $34^{\circ} \mathrm{C}$ (Crowe in sod., 2013). Sahu in sod. (2013) so ugotovili, da v prvi uri pobiranja riža pri vrednostih WBGT $27^{\circ} \mathrm{C}$ delavci $\mathrm{v}$ povprečju poberejo 86 svežnjev, pri vrednostih $31^{\circ} \mathrm{C}$ pa le še 65 . V raziskavi na Cipru so delavci v vinogradu tekom poletja $87 \%$ časa delali pri vrednostih WBGT, višjih od $25^{\circ} \mathrm{C}$ (Ioannou in sod., 2017).

Za zagotavljanje normalnega delovanja organov moramo telesno temperaturo ohranjati na $37^{\circ} \mathrm{C}$, najbolj običajen način hlajenja je potenje. Raziskave so pokazale, da se ženske potijo manj kot moški, potiti pa se začnejo pri višji telesni temperaturi, zato je pri njih večje tveganje za simptome vročinskega stresa ali $\mathrm{z}$ vročino izzvane bolezni (Staal Wästerlund, 2018). To se je potrdilo tudi $\mathrm{v}$ raziskavi med slovenskimi delavci $\mathrm{v}$ kmetijstvu, kjer so ženske $\mathrm{v}$ večjem deležu navajale težave zaradi vročinskega stresa (Pogačar in sod., 2017). Razpon potrebne količine popite tekočine je zelo velik od dveh litrov na dan pri lahkem delu in vrednostih WBGT okoli $10{ }^{\circ} \mathrm{C}$ do 15 litrov pri izredno napornem delu in vrednostih WBGT okoli $30{ }^{\circ} \mathrm{C}$ (Staal Wästerlund, 2018).

Dodatno toplotno obremenitev, ki je kazalnik WBGT ne prikaže, pomenijo pretople, t.i. tropske noči, ko se tudi ponoči temperatura zraka ne spusti pod $20^{\circ} \mathrm{C}$. Takrat se delavci med nočnim počitkom večinoma slabo odpočijejo in naslednji dan že začnejo utrujeni. Zanimivo je, da se je v Ljubljani to zgodilo že po prvem dnevu prvega vročinskega vala leta 2017 , ko je bila najnižja 24-urna temperatura zraka $23,8^{\circ} \mathrm{C}$. Dve tropski noči sta bili še ob koncu drugega vročinskega vala, ena predzadnji dan tretjega ter štiri z vmesno prekinitvijo ob koncu četrtega vala. V Biljah sta bili tropski zadnji dve 
noči prvega vročinskega vala, zadnja noč drugega, druga noč tretjega in prva noč petega vročinskega vala. $\mathrm{V}$ najhujšem, četrtem vročinskem valu je bilo kar pet tropskih noči. Številne raziskave so pokazale, da nočne temperature zraka naraščajo hitreje kot dnevne, prav tako modeli za prihodnost napovedujejo, da se bo ta trend nadaljeval (Peng in sod., 2013). Tudi za Slovenijo velja, da se zadnja leta pojavljajo rekordno visoke nočne temperature (Sušnik in Pogačar, 2011; Vertačnik, 2014), kar za delavce pomeni še dodatno toplotno obremenitev, ki jo bo v nadaljnjih raziskavah potrebno upoštevati.

\section{SKLEPI}

Analiza vročinskih valov za obdobje 1961-2017 za Ljubljano in Bilje je pokazala, da je število dni v vročinskih valovih začelo močno naraščati po letu 1990 na obeh lokacijah. Prav tako se je povečala intenziteta vročinskih valov, saj povprečne dnevne temperature zraka dosegajo precej večje vrednosti kot v prvi polovici obravnavanega obdobja. Podaljšuje se časovni razpon, v katerem se pojavljajo, na obeh lokacijah je jasno vidno, da se pred letom 1990 vročinski valovi niso pojavljali zgodaj junija in pozno avgusta, $\mathrm{v}$ zadnjih dveh desetletjih je takšna časovna razporeditev postala običajna. Leta 2017 je tako v Ljubljani kot v Biljah nastopilo 5 vročinskih valov, dolgih od 3 do 7 (Bilje) oziroma 8 (Ljubljana) dni, za katere smo izračunali kazalnik WGBT za oceno tveganja vročinskega stresa pri delavcih v kmetijstvu.

Nekatere mejne vrednosti so redno presežene tudi $\mathrm{v}$ Sloveniji, torej je primerno, da kazalnik WBGT uporabimo za prikaz toplotne obremenitve delavcev. V Ljubljani vrednosti kazalnika WBGT sicer niso nikoli presegle mejne vrednosti $28^{\circ} \mathrm{C}$ (meja za običajno kmetijsko delo), $\mathrm{v}$ najhujšem vročinskem valu so presegle vrednost $25^{\circ} \mathrm{C}$ (težje delo), v vseh vročinskih valovih pa vsaj za nekaj ur $23{ }^{\circ} \mathrm{C}$ (fizično izredno naporno delo). Temperatura zraka in vlaga sta bili $\mathrm{v}$ Biljah glede na Ljubljano toliko bolj obremenilni, da je bila skoraj $\mathrm{v}$ vseh dneh $\mathrm{v}$ vročinskih valovih presežena tudi mejna vrednost WBGT $25^{\circ} \mathrm{C}$. Poleg tega je bila $\mathrm{v}$ Biljah v najhujšem vročinskem valu v začetku avgusta $\mathrm{v}$ petih dneh za vsaj pet ur (med 12. in 17. uro) presežena tudi mejna vrednost $28^{\circ} \mathrm{C}$. Pri preseženih mejnih vrednostih WBGT bi morali delodajalci oziroma kmetje sami uvesti preventivne ukrepe za zmanjšanje tveganja vročinskega stresa, na primer reorganizirati delo, uvesti več rednih odmorov na hladnem, piti več tekočine in nositi primerna oblačila.

\section{ZAHVALA}

Raziskava je bila finančno podprta s strani okvirnega programa EU za razvoj in inovacije Obzorje $2020 \mathrm{~s}$ pogodbo št. 668786. Zahvaljujemo se prof. Larsu Nybu,
Andreasu Flourisu in Tordu Kjellstromu za vodenje projekta.

\section{VIRI}

ARSO. (2013). Podnebna spremenljivost Slovenije: Glavne značilnosti gibanja temperature zraka $v$ obdobju 1961-2011. Dostopno na: http://meteo.arso.gov.si/uploads/probase/www/clim ate/text/sl/publications/PSS-Glavne-znacilnostigibanja-temperature-zraka-1961-2011.pdf

ARSO. (2017). Ocena podnebnih sprememb v Sloveniji do konca 21. stoletja: Povzetek temperaturnih in padavinskih povprečij. Dostopno na: http://meteo.arso.gov.si/uploads/probase/www/clim ate/text/sl/publications/povzetek-podnebnihsprememb-temp-pad.pdf

Bernard, T. E., Pourmoghani, M. 1999. Prediction of Workplace Wet Bulb Global Temperature. Applied Occupational and Environmental Hygiene, 14, 126134. doi:10.1080/104732299303296
Bittner, M.I., Matthies, E.F., Dalbokova, D., Menne, B. (2013) Are European countries prepared for the next big heat-wave? European Journal of Public Health, 24(4), 615-619. doi:10.1093/eurpub/ckt121

Crowe, J., Wesseling, C., Roman Solano, B., Umana, M.P., Ramírez, A.R., Kjellstrom, T., Morales, D., Nilsson, M. (2013). Heat exposure in sugarcane harvesters in Costa Rica. American Journal of industrial Medicine, 56(10), 1157-1164. doi:10.1002/ajim.22204

d'Ambrosio Alfano, F.R., Palella, B.I., Riccio, G., Malchaire, J. (2016). On the Effect of Thermophysical Properties of Clothing on the Heat Strain Predicted by PHS Model. The Annals of Occupational Hygiene, 60(2), 231-251. doi:10.1093/annhyg/mev070

Acta agriculturae Slovenica, 111 - 3, december 2018 
Flouris, A. D., McGinn, R., Poirier, M. P., Louie, J. C., Ioannou, L. G., Tsoutsoubi, L., Sigal, R. J., Boulay, P., Hardcastle, S. G., Kenny, G. P. (2018). Screening criteria for increased susceptibility to heat stress during work or leisure in hot environments in healthy individuals aged $31-70$ years. Temperature, 5, 86-99. doi:10.1080/23328940.2017.1381800

Gao, C., Kuklane, K., Östergren, P. O., Kjellstrom, T. (2018). Occupational heat stress assessment and protective strategies in the context of climate change. International Journal of Biometeorology, 62, 359-371. doi:10.1007/s00484-017-1352-y

Gubernot, D.M., Andersson, G.B., Hunting, K.L. (2015). Characterizing occupational heatrelated mortality in the United States, 2000-2010: An analysis using the census of fatal occupational injuries database. American Journal of Industrial Medicine, 58(2), 203-211. doi:10.1002/ajim.22381

Ioannou, L. G., Tsoutsoubi, L., Samoutis, G., Kajfez Bogataj, L., Kenny, G.P., Nybo, L., Kjellstrom, T., Flouris, A. D. (2017). Time-motion analysis as a novel approach for evaluating the impact of environmental heat exposure on labor loss in agriculture workers. Temperature, 4, 330-340. doi:10.1080/23328940.2017.1338210

Kajfež Bogataj, L., Katkić, V., Pogačar, T. (2018). Vpliv podnebnih sprememb na povečano rabo energije za klimatizacijo. V: Lipič, K. (ur.), Rižnar, K. (ur.). Nacionalni program varstva okolja in njegov dialog z lokalnimi skupnostmi : strokovno posvetovanje 2018, Moravske Toplice, Hotel Ajda, 5. in 6. april 2018. Ljubljana: Zveza ekoloških gibanj Slovenije, str. 145-152.

Kjellstrom, T., Holmer, I., Lemke, B. (2009). Workplace heat stress, health and productivity - an increasing challenge for low and middle income countries during climate change. Global Health Action, 2(1), 2047. doi:10.3402/gha.v2i0.2047

Kjellstrom, T., Freyberg, C., Lemke, B., Otto, M., Briggs, D. (2018). Estimating population heat exposure and impacts on working people in conjunction with climate change. International Journal of Biometeorology, 62(3), 291-306. doi:10.1007/s00484-017-1407-0

Ključevšek, N., Hrabar, A., Dolinar, M. (2018). Podnebne podlage za definicijo vročinskega vala. Vetrnica, 10, 44-53.

Kuglitsch, F.G., Toreti, A., Xoplaki, E., Della-Marta, P.M., Zerefos, C.S., Türkeş, M., Luterbacher, J. (2010). Heat wave changes in the eastern Mediterranean since 1960. Geophysical Research Letters, 37. doi:10.1029/2009GL041841
Lemke, B., Kjellstrom, T. (2012). Calculating Workplace WBGT from Meteorological Data: A Tool for Climate Change Assessment. Industrial Health, 50(4), 267-278. doi:10.2486/indhealth.MS1352

Lundgren, K., Kuklane, K., Venugopal, V. (2014). Occupational heat stress and associated productivity loss estimation using the PHS model (ISO 7933): a case study from workplaces in Chennai, India. Global Health Action, 2014 (7). doi:10.3402/gha.v7.25283

McPherson, M. J. (2008). Subsurface Ventilation and Environmental Engineering, 2nd Ed., Ch. 17. Physiological reactions to climatic conditions. Mine Ventilation Services Inc., Clovis. http://www.mvsengineering.com/index.php?cPath= 25

Morabito, M., Crisci, A., Messeri, A., Messeri, G., Betti, G., Orlandini, S., Raschi, A., Maracchi, G. (2017). Increasing Heatwave Hazards in the Southeastern European Union Capitals. Atmosphere, 8(7), 115. doi:10.3390/atmos8070115

Peng S., Piao S., Ciais P., Myneni R.B., Chen A., Chevallier F., Dolman A.J., Janssens I.A., Penuelas J., Zhang G., Vicca S., Wan S., Wang S., Zeng H. 2013. Asymmetric effects of daytime and nighttime warming on Northern Hemisphere vegetation. Nature, 501, 88-92. doi:10.1038/nature12434

Pogačar, T., Črepinšek, Z., Kajfež Bogataj, L., Nybo, L. (2017). Comprehension of climatic and occupational heat stress amongst agricultural advisers and workers in Slovenia. Acta Agriculturae Slovenica, 109(3), 545-554. doi:10.14720/aas.2017.109.3.06

Pogačar, T., Casanueva, A., Kozjek, K.,Ciuha, U., Mekjavić, I., Kajfež Bogataj, L., Črepinšek, Z. (2018). The effect of hot days on occupational heat stress in the manufacturing industry: implications for workers' well-being and productivity. International Journal of Biometeorology. doi:10.1007/s00484-018-1530-6

Russo, S., Sillman, J., Fischer, E.M. (2015). Top ten European heatwaves since 1950 and their occurrence in the coming decades. Environmental Research Letters, 10(12), 124003. doi:10.1088/1748-9326/10/12/124003

Sahu, S., Sett, M., Kjellstrom, T. (2013). Heat exposure, cardiovascular stress and work productivity in rice harvesters in India: implications for a climate change future. Industrial Health, 51(4), 424-431. doi:10.2486/indhealth.2013-0006 
Staal Wästerlund, D. (2018). Managing heat in agricultural work: increasing worker safety and productivity by controlling heat exposure. Forestry Working Paper No. 1. Rome, FAO. 53 str.

Sušnik, A., Pogačar, T. 2011. Vremensko povzročeni stresi kmetijskih rastlin v letu 2011. Ujma, 25, 8192.
Vertačnik, M. (2014) Ekstremne temperature in njihova spremenljivost $v$ Sloveniji $v$ obdobju 1961-2013. Diplomska naloga. Ljubljana, Biotehniška fakulteta, oddelek za agronomijo: 36 str. 